\title{
PENGARUH ELEMEN EKUITAS MEREK TERHADAP KEPUTUSAN PEMBELIAN PRODUK PASTA GIGI PEPSODENT DIKECAMATAN KINALI
}

\author{
JON MAIZAR \\ Universitas Putra Indonesia YPTK Padang, Indonesia \\ Email : maizarjon@ rocketmail.com
}

\begin{abstract}
ABSTRAK
Penelitian ini bertujuan untuk mengetahui bagaimana Pengaruh Kesadran merek terhadap keputusan pembelian, Pengaruh asosiasi merek terhadap keputusan pembelian, Pengaruh presepsi kualitas terhadap keputusan pembelian, Pengaruh loyalitas merek terhadap keputusan pembelian. Pengaruh elemen ekuitas merek terhadap keputusan pembelian produk pasta gigi pepsodent dikecamatan kinali. Penelitian ini termasuk kedalam penelitian asosiatif dengan menggunakan pengolahan data kuantitatif. Populasi dalam peneliatian ini adalah masyarakat kecamatan kinali yang menggunakan produk pasta gigi pepsodent. Teknik yang digunakan untuk menentukan sampel adalah accidental sampling menurt sugiyono (2004). Karna jumlah sampel tidak diketahui maka penilis mengambil 100 orang yang menggunakan produk pasta gigi pepsodent untuk dijadikan sampel. Data dikumpulkan melalui kusioner untuk mengukur variabel penelitian yang dikuantifisir dengan skala likert. berdasarkan hasil penelitian yang dilakukan analisis menujukan bahwa Kesadaran merek tidak berpengaruh positif dan signifikan terhadap keputusan pembelian, Asosiasi Merek tidak berpengaruh positif dan signifikan terhadap keputusan pembelian. Persepsi kualitas berpengaruh positif dan signifikan terhadap keputusan pembelian. Bila diuji secara simultan, Loyalitas Merek tidak berpengaruh positif dan signifikan terhadap keputusan pembelian. Kesadaran Merek, Asosiasi Merek, Presepsi Kualitas dan Loyalitas Merek, diantara ke empat variabel tersebut, hanya 1 variabel yang memiliki pengaruh sedangkan 3 lainya tidak memiliki pengaruh terhadap keputusan pembelian, dan nilai Koefesien Determinasi sebesar $40 \%$ dan sisanya sebesar $60 \%$ lagi dipengaruhi oleh variabel lain yang tidak diteliti pada penelitian ini.
\end{abstract}

Primary Key: Kesadaran Merek, Asosiasi Merek, Presepsi Kualitas, Loyalitas Merek dan Keputusan Pembelian.

\section{Pendahuluan}

Manusia dalam kehidupan sehari-hari harus memenuhi kebutuhan untuk hidup sehat salah satu nya adalah mengenai kesehatan dan kebersihan gigi. Seseorang yang gigi nya bersih akan memiliki penampilan yang menarik dan timbul rasa percaya diri saat berbaur dengan orang lain. Pasta gigi merupakan salah satu kebutuhan yang sangat penting bagi konsumen untuk pemeliharaan kesehatan gigi dan gusi, kesedaran masyarakat akan penting nya kesehatan gigi membuat produsen pasta gigi berpacu menciptakan produk pasta gigi yang sesuai dengan ekspetasi masyarakat.

Saat ini cukup banyak merek pasta gigi yang beredar di masyarakat dengan beragam fitur cukup banyak close-up, ciptadent, formula, siwak f, enzim ritadent dan pepsodent dari sekian merek pasta gigi tersebut diatas salah satu merek yang paling menonjol namun menghadapi pesaing yang ketat adalah pasta gigi merek pepsodent. Pepsodent merupakan merek pasta gigi dari berbagai produk yang dihasilkan oleh PT. Unilever Tbk, dengan konsep positioning sebagai pasta gigi keluarga Indonesia.

Agar produk pasta gigi pepsodent mampu bertahan dan berkembang di tengah persaingan yang ketat disekitar produk pasta gigi manajement pemasaran dengan baik terutama menerapkan strategi pemasaran yang berfokus pada peningkatan bobot keputusan konsumen. Agar produsen pepsodent dapat menerapkan strategi meningkatkan bobot keputusan pembelian Konsumen nya, maka harus di ketahui terlebih dahulu faktor-faktor yang mempengaruhi keputusan pembelian 
pepsodent di kecamatan kinali. David Aaker menyatakan bahwa faktor-faktor yang mempengaruhi keputusan pembelian adalah Marketing Mix, Faktor Budaya, Faktor Sosial, Pelayanan, Ekuitas Merek Agar perusahaan dapat mempertahankan eksistensinya dalam dunia usaha, salah satu upaya yang dapat dilakukan perusahaan adalah dengan membentuk identitas produk yang lebih kuat melalui persaingan merek, merek dapat memberi nilai tambah pada nilai yang ditawarkan oleh produk kepada pelanggan nya merek juga digunakan sebagai suatu tanda suatu produk di kalangan masyarakat yang memiliki kekuatan untuk tujuan pertama produk itu di ciptakan. Hal ini sesuai yang di katakan shadat (2009) merek memberikan nilai sehingga nilai total produk yang bermerek menjadi lebih tinggi di bandingkan produk yang di nilai sematamata secara objektif. Merek bukan hanya lagi kata-kata yang hanya di hubungkan dengan produk atau sekumpulan barang pada era perdagangan bebas sekarang ini tetapi juga proses dan strategi bisnis. Oleh karena itu merek mempunyai nilai atau ekuitas, dan ekuitas menjadi sangat penting karna nilai tersebut akan menjadi tolak ukur suatu produk yang ada dipasaran.

Ekuitas merek dapat dilelompokan dalam 5 elemen yaitu; Kesadaran Merek (brand awareness) , Presepsi Kualitas ( perceived quality) Asosiasi Merek (brand assciation) Loyalitas Merek ( brand loyality) (aaeker, 1991).

Menurut aaker (2007) kesadaran merek (Brand Awarenness) adalah kemampuan dari seseorang yang merupakan calon pembeli (potencial buyer) untuk mengenali (recognize) atau menyebutkan kembali (recall) suatu merek merupakan bagian dari suatu kategori produk. Persepsi kualitas mengandung arti bagaimana cara seseorang dalam memahami sesuatu dan bagaimana ia melihat atau menafsirkan suatu objek produk atau informasi yang diperoleh melalui sistem indera manusia.

Presepsi kualitas ( perceived quality) didefinsikan sebagai presepsi pelanggan terhadap keseluruhan kualitas atau keunggulan suatu produk atau jasa yang berkenaan dengan maksud yang diharapkan ( susanto dan wijarnako (2004)

Asosiasi merek (Brand Accocation) adalah segala sesuatu yang berhubungan dengan ingatan pada merek dan memuat arti penting suatu merek bagi konsumen (keller,2003). Asosiasi merek adalah segala hal yang berkaitan dengan merek dalam ingatan ( simamora ,2001).

Loyalitas Merek ( brand loyality) merupakan komitmen kuat dalam membeli atau berlangganan kembali suatu produk atau jasa yang dipilih secara konsisten dimasa mendatang (Aaker, 1991) Loyalitas merek merupakan suatu ukuran keterkaitan pelanggan kepada sebuah merek ( durianto et al.2004.)

Berdasarkan uraian-uraian tersebut diatas, maka peneliti mengambil judul penelitian “ Pengaruh Elemen Ekuitas Merek Terhadap Keputusan Pembelian Produk Pasta Gigi Pepsodent”(Studi Kasus Pada Masyarakat Kecamatan Kinali Kabupaten Pasaman Barat).

\section{Landasan Teori}

\subsection{Keputusan Pembelian}

Menurut Kotler dan Keller (2009) keputusan pembelian seseorang merupakan hasil dari suatu proses yang terdiri dari lima tahapan yaitu pengenalan, kebutuhan, pencarian, pencarian informasi , pengevaluasian alternatif,keputusan pembelian dan perilaku setelah pembelian itu sendiri. Sciffman dan Kanuk ( 2008) menjelaskan bahwa keputusan pembelian adalah pemilihan dari dua atau lebih alternatif pilihan yang ada artinya bahwa syarat seseorang dapat membuat keputusan pembelian haruslah tersedia bberapa alternatif pilihan.

Menurut Suharno (2010) tahap dimana pembeli telah menentukan pilihan nya dan melakukan pembeliaan produk serta mengkonsumsi nya.Pengambilan keputusan oleh konsumen untuk melakukan pembelian suatu produk di awali oleh adanya kesadaran atas kebutuhan keinginan, selanjut nya jika sdah disadari adanya keutuhan dan keinginan maka konsumen akan mencari informasi mengenai kebradaan produk yang di inginkan. 


\subsection{Elemen Ekuitas Merek}

Kotler dan Amstrong (2011) mendefinisikan ekuitas merek sebagai efek pembeda positif dari respon konsumen atas suatu barang dan jasa sebagai akibat dari pengetahuan konsumen atas nama merek dari barang dan jasa tersebut. Ekuitas merek dapat di artikan dalam berbagai sudut pandang dalam persepektif pemasaran sendiri salah satu nya yang banyak dikutip adalah definisi dari Davit Aaker ( 1997) yang menyatakan bahwa ekuitas merek adalah serangkaian aset dan kewajiban merek yang terkait degan sebuah merek, nama dan simbol nya yang menambah atau mengurangi nilai yang diberikan sebuah produk atau jasa kepada perusahaan atau konsumen perusahaan tersebut .

Menurut Kotler dan Keller (2009) ekuitas merek berbasis kosumen dapat didefinisikan sebagaiperbedaan dampak dari penetahuan merek terhadap tanggapan konsumen pada merek tersebut, suatu dapat dikatakan memiliki ekuitas merek berbasis konsumen yang positif apabila konsumen menyenangkan terhadap produk tertentu. Sebalik nya suatu merek adapat dikatakan memiliki ekuitas merek berbasis konsumen yang negatif apabila konsumen kurang menyenangkan terhadap aktifitas pemasaran merek dalam situasi yang sama.

Konsumen cenderung membeli produk dengan merek yang mereka kenal, karena pada dasarnya masyarakat akan merasa aman dengan sesuatu yang sudah mereka kenal. Oleh karena itu dapat disimpulkan bahwa biasanya merek yang sudah dikenal memiliki kemungkinan bahwa merek tersebut bisa diandalkan, kemantapan dalam bisnis, dan kualitas yang bisa dipertanggungjawabkan. Tentunya kesadaran merek tersebut juga menentukan keputusan pembelian konsumen.

\subsection{Kesadaran Merek (Brand Awarness)}

Menggambarkan keberadaan merek didalam pikiran konsumen, yang menjadi penentu dalam beberapa kategori dan biasanya mempunyai pernan kunci brand ekiti. Meningkatkan kesadaran adalah suatu mekanisme untuk memperluas pasar merek. Kesadaran merek merupakan key of brand asset atuu kunci pembuka untuk masuk ke elemen lainnya.jika kesadaran itu rendah maka hampir di pastikan bahwa ekuitas merek nya juga rendah ( Darmadidurianto 2004).

Surachman (2008) mendefinisikan kesadaran merek adalah kesanggupan seorang pembeli untuk mengenali atau mengingat kembali bahwa suatu merek merupakan bagian dari kategori produk tertentu. Peran Kesadaran merek dalam brand equity tergantung pada tingkatan akan pencapaian kesadarn dibenak konsumen. Menurut Aaker (2013) menerangkan kesadaran merek mempengaruhi rasa percaya diri pelanggan atas keputusan pembelian dengan mengurangi tingkat resiko yang dirasakan atas suatu merek yang diputuskan untuk dibeli.

\subsection{Persepsi Kualitas ( Perceived Quality)}

Menurut Simamora (2007), presepsi kualitas adalah presepsi pelanggan terhadap kualitas atau keunggulan suatu produk atau jasa layanan ditinjau dari fungsinya secara relatif dengan produk-produk lain.

Menurut Dvid A.Garvin (2011) dimensi presepsi kualitas dibagi menjadi tujuh :

1. Kinerja : Melibat kan berbagai karakteristik operasional utama, karena faktor kepentingan konsumen berbeda satu sama lain.

2. Pelayanan : Mencerminkan kemampuan memberi pelayanan pada produk tersebut.

3. Ketahanan : Mencerminkan umur ekonomis dari produk tersebut.

4. Keandalan : Konsistensi dari kinerja yang dihasilkan suatu produk dari satu pembelian kepembelian berikut nya.

5. Karakteristik produk : Bagian tambahan dari produk ( feature) 
6. Kesesuain dengan spesifikasi : Merupakan pandangan mengenai kualitas proses manufaktur ( tidak cacat produk) sesuai dengan spesifikasi yang telah ditentukan dan teruji.

7. Hasil : mengarah pada kualitas yang dirasakan.

Presepsi kualitas merupakan presepsi konsumen yang yang dikomunikasikan bahwa merek tersebut kualitkas atau layanan atau keunggulan dari merek tersebut langsung diketahui oleh konsumen.Presepsi kualitas merupakan kunci utama dalam dimensi ekuitas merek .Presepsi konsumen mengenai keseluruhan kualitas suatu produk atau jasa mampu mempengaruhi konsumen tersebut dalam melakukan keputusan pembelian, hal tersebunmt dapat dilihat dari nilai presepsi kualitas sebagai alasan konsumen untuk membeli suatu produk ( Moradi 2013).

\subsection{Asosiasi Merek ( Brand Association)}

Adalah sesuatu yang berkaitan dengan ingatan mengenai sebuah produk .Asosiasi ini tidak hanya eksis namun juga memiliki suatu tingkat kekuatan.Keterikatan akan sebuah merek akan lebih kuat apabila dilandasi pada banyak pengalaman atau penampakan untuk mengkomunikasikannya. ( Susanto dan wijarnako,2004). Simamora (2007) berpendapat bahwa asosiasi merek asosiasi merek adalah segala hal yang berkaitan tentang merek dalam ingatan. Sedangkan menurut durianto Et Al ( 2004), asosiasi merek merupakan segala kesan yang muncul dibenak seseorang yang terkait dengan ingatannya mengenai suatu merek.

\subsection{Loyalitas Merek (Brand Loyality)}

Loyalitas Merek ( brand loyality) merupakan komitmen kuat dalam membeli atau berlangganan kembali suatu produk atau jasa yang dipilih secara konsisten dimasa mendatang (Aaker, 1991) Loyalitas merek merupakan suatu ukuran keterkaitan pelanggan kepada sebuah merek ( durianto et al.2004.)

Menurut wirastomo (2012) hasil yang ditemukan menyatakan bahwa tingkat brand loyality yang tinggi yaitu berupa komitmen yang kuat dari pelanggan terhadap merek yang dapat menciptakan rasa percaya diri yang besar pada pelanggan saat mengambil keputusan pembelian.

\section{Metodologi Penelitian 3.1 Jenis Penelitian}

Penelitian ini merupakan penelitian kuantitatif dan berdasar tingkat eksplanasi asosiatif (assosiatif research) yang akan membuktikan pengaruh variabel bebas terhadap variabel terikat. Pendekatan kuantitatif digunakan untuk meneliti pada populasi atau sampel tertentu dengan menggunakan instrumen penelitian, analisis data yang bersifat statistik dengan tujuan untuk menguji hipotesis yang telah ditetapkan, Sugiyono, (2010).

\subsection{Tempat dan waktu Penelitian}

Penelitian ini dilakukan dikecamatan kinali dan waktu dilaksanakannya penelitian ini yaitu sejak Februari s/d Juni 2018.

\subsection{Populasi Dan Sampel}

Populasi adalah kumpulan dari semua kemungkinan orang-orang, benda-benda, dan ukuran lain, yang menjadi objek perhatian atau kumpulan seluruh objek yang menjadi perhatian, Suharyadi \& Purwanto (2011). Dengan demikian populasi dalam penelitian ini adalah masyarakat kecamatan kinali yang menggunakan produk pasta gigi pepsodent. 
Sampel adalah subset dari populasi, terdiri dari beberapa anggota populasi. Subset ini di ambil karena dalam banyak kasus tidak mungkin kita meneliti seluruh anggota populasi, oleh karena itu kita membentuk sebuah perwakilan yang disebut sampel. Ferdinand (2006). Penelitian sampel dalam penelitian ini adalah dengan accidental sampling. Accidental sampling adalah teknik penentuan sampel berdasarkan kebetulan, yaitu siapa saja yang kebetulan/insidental bertemu dengan peneliti dapat digunakan sebagai sampel, bila dipandang orang yang kebetulan ditemui itu cocok sebagai sumber data.

Mengingat jumlah masyarakat kecamatan kinali yang menggunakan produk pasta gigi pepesodent tidak diketahui, maka dalam menentukan jumlah sampel penulis merujuk kepada pendapat Santoso, (2007) dimana untuk sampel yang tidak diketahui jumlah pastinya maka jumlah sampel yang dianjurkan antara 50-100 sampel. Alasan penggunaan metode ini karena keterbatasan waktu dan lebih efisien, sehingga penulis tetapkan jumlah sampel sebanyak 100 orang sampel. Teknik yang digunakan menurut Sugiyono (2009) adalah teknik non probabilitas sampling adalah semua objek atau elemen populasi tidak mempunyai kesempatan yang sama untuk dipilih sebagai sampel.

\subsection{Sumber Data}

Sumber data yang dijadikan acuan didalam pengolahan data dalam penelitian ini terbagi menjadi 2 (dua) yaitu:

1. Data Primer

Data primer adalah data yang diperoleh dengan survei lapangan yang menggunakan semua metode pengumpulan data original, Kuncoro 2004).

2. Data Sekunder

Data sekunder adalah data yang biasanya telah dikumpulkan oleh lembaga pengumpul data dan dipublikasikan kepada masyarakat pengguna data Kuncoro (2004).

\subsection{Instrumen Dan Teknik Pengumpulan Data}

Disini penulis melakukan penelitian dengan instrumen berupa kusioner yang berisikan berupa pernyataan-pernyataan, yang di berikan kepada sejumlah sampel yang mewakili populasi dengan metode skala likert.

Adapun teknik pengumpulan data dalam penelitian ini adalah :

1. Teknik kusioner

2. Teknik Observasi

\subsection{Teknik Analisa Data}

Adapun teknik analisa data yang dilakukan dalam penelitian ini yaitu uji validitas dan reabillitas, stasistik deskriptif, uji koefisien korelasi, uji asumsi klasik dan uji regresi linear berganda.

\section{Hasil dan Pembahasan Penelitian}

Dalam penelitian ini penulis menyebarkan 100 angket kuesioner kepada masyarakat kecamatan kinali, Kuesioner ini terdiri dari empat bagian yaitu, tanggapan responden tentang kesadaran merek, presepsi kualitas, asosiasi merek dan loyalitas merek atas keputusan pembelian produk pasta gigi pepsodent di kecamatan kinali. 


\subsection{Profil Responden}

Gambaran umum responden ini untuk mengetahui tentang karakteristik dari masyarakat kecamatan Kinali yang terpilih sebagai sampel. Pengolongan terhadap masyarakat didasarkan pada jenis kelamin, status perkawinan, usia , pekerjaan, pendidikan terakhir, lama menggunakan pepsodent.

Dari pengolongan ini akan dapat memperoleh suatu gambaran mengenai keadaan responden. Pengolongan tersebut disajikan dalam tabel dalam tabel 4.2 sampai dengan tabel 4.7

Tabel 4.2

Tabel Frekuensi Berdasarkan Jenis Kelamin

\begin{tabular}{|l|l|l|}
\hline \multicolumn{1}{|c|}{ Jenis Kelamin } & \multicolumn{1}{|c|}{ Frekuensi } & \multicolumn{1}{c|}{ Persentase } \\
\hline Laki-laki & 40 & 42,6 \\
\hline Perempuan & 54 & 57,4 \\
\hline Total & 94 & $100 \%$ \\
\hline
\end{tabular}

Sumber : Data Primer 2018

Berdasarkan jenis kelamin yang diperoleh dari responden yang ada, maka diketahui $42,6 \%$ merupakan responden Laki-laki dan 57,4\% adalah responden perempuan.

Tabel 4.3

Tabel Frekuensi Berdasarkan Satatus Perkawinan

\begin{tabular}{|l|l|l|}
\hline Status Perkawinan & Frekuensi & Persentase \\
\hline Menikah & 34 & 36,2 \\
\hline Belum Menikah & 49 & 52,1 \\
\hline Janda / Duda & 11 & 11,7 \\
\hline Total & 94 & $100 \%$ \\
\hline
\end{tabular}

Sumber : Data Primer, 2018

Distribusi responden berdasarkan status perkawinan sebesar 36,2\% berstatus menikah, sebesar $52,1 \%$ responden belum menikah dan $11,7 \%$ responden janda/ duda . Berdasarkan penjelasan diatas dapat disimpulkan bahwa yang menjadi responden sebagian besar adalah responden yang responden belum menikah.

Tabel 4.4

Tabel Frekuensi Berdasarkan umur

\begin{tabular}{|l|l|l|}
\hline Umur & Frekuensi & Persentase \\
\hline Dibawah 30 th & 50 & 53,2 \\
\hline 30 S/d 40 th & 25 & 26,6 \\
\hline Di Atas 40 th & 19 & 20,2 \\
\hline Total & 94 & $100 \%$ \\
\hline Sumber : Data Primer 2018
\end{tabular}

Dari tabel diatas umur responden yang berada pada usia produktif dibawah 30th sebesar 53,2\% . Berdasarkan penjelasan diatas dapat disimpulkan yang menjadi responden sebagian besar adalah responden yang berada dibawah 30th

Tabel 4.5

Tabel Frekuensi Berdasarkan Pekerjaan

\begin{tabular}{|l|l|l|}
\hline Pekerjaan & Frekuensi & Persentase \\
\hline
\end{tabular}




\begin{tabular}{|l|l|l|}
\hline Murid SD & 5 & 5,3 \\
\hline Karyawan Swasta & 8 & 8,5 \\
\hline $\begin{array}{l}\text { Pengusaha } \\
\text { Wiraswasta }\end{array}$ & 5 & 5,3 \\
\hline Siswa SMP / SMA & 25 & 26,6 \\
\hline Guru & 18 & 19,1 \\
\hline Petani & 12 & 12,8 \\
\hline Mahasiswa & 9 & 9,6 \\
\hline Pedagang & 9 & 9,6 \\
\hline Lain2 ... & 3 & 3,2 \\
\hline Total & 94 & $100 \%$ \\
\hline Sumber : Data Primer, 2018 & &
\end{tabular}

Berdasarkan tabel di atas menjelaskan bahwa responden yang berasal dari kalangan siswa SMP/ SMA dengan rincian 25 orang ( $26,6 \%$ ) kemudian responden yang berasal dari kalangan guru dengan rincian 18 orang $(19,1)$,Petani 12 orang ( $12,8 \%)$, Mahasiswa 9 orang $(9,6 \%)$ ,Pedagang 9 orang $(9,6 \%)$, Karyawan swasta 8 orang ( $8,5 \%)$, Murid SD 5 orang $(5,3 \%)$, Pengusaha/ wiraswasta 5 orang ( $5,3 \%)$, Lain-lain 3 orang $(3,2 \%)$.

Tabel 4.6

Tabel Frekuensi Berdasarkan Pendidikan

\begin{tabular}{|l|l|l|}
\hline $\begin{array}{l}\text { Pendidikan } \\
\text { Terakhir }\end{array}$ & Frekuensi & Persentase \\
\hline SD/ MI & 11 & 11,7 \\
\hline SLTP/ Sederjat & 24 & 25,5 \\
\hline SLTA/ Sederajat & 34 & 36,2 \\
\hline Diploma & 2 & 2,1 \\
\hline Sarjamna S1 & 20 & 21,3 \\
\hline Pasca Sarjana S2 S3 & 3 & 3,1 \\
\hline Total & 94 & $100 \%$ \\
\hline
\end{tabular}

Sumber : Data Primer, 2018

Berdasarkan tabel diatas diketahui bahwa responden yang paling dominan berasal dari tingkat SMA sebanyak 34 orang ( $36,2 \%$ ) kemudian respoden yang berpendidikan SLTP yaitu sebanyak 24 orang $(25,5 \%)$ yang brpendidikan S1 Sebanyak 20 orang $(21,3)$ yg berpendidikan SD sebanyak 11 orang $(11,7 \%)$ diploma 2 orang $(2,1 \%)$. hal tersebut mengindikasikan bahwa sebagian besar responden yang diteliti adalah responden yang tingkat pendidikan sma sederajat.

Tabel 4.7

Tabel Frekuensi Berdasarkan lama Menggunakan Pepsodent

\begin{tabular}{|l|l|l|}
\hline $\begin{array}{l}\text { Lama Menggunakan } \\
\text { Pepsodent }\end{array}$ & Frekuensi & Persentase \\
\hline Dibawah 1 tahun & 1 & 1,1 \\
\hline 1 s/d 3 tahun & 1 & 1,1 \\
\hline Diatas 3 tahun & 89 & 94,7 \\
\hline 4 & 3 & 3,2 \\
\hline Total & 94 & $100 \%$ \\
\hline
\end{tabular}

Sumber Data Primer 2018 


\subsection{Pengujian Instrumen Uji Validitas dan Uji Reliabilitas}

Sebelum melakukan analisis deskriptif dan pengujian hipotesis terlebih dahulu dilakukan pengujian instrumen. Pengujian instrumen digunakan untuk mendapatkan data yang sahih (valid) dan handal (reliabel) secara empiris.

\subsubsection{Uji Validitas}

Sugiyono (2007) menyatakan bahwa syarat minimum untuk dianggap memenuhi syarat validitas adalah $r$ hitung $>0,3$. Jadi, apabila diperoleh $r$ hitung lebih besar dari 0,3 maka butir pernyataan dalam instrumen penelitian dinyatakan valid. Hasil validitas kuisioner akan dijelaskan berikut ini:

\subsubsection{Hasil Uji Validitas Variabel Keputusan Pembelian}

Variabel keputusan pembelian pada penelitian ini di ukur dengan menggunakan 5 butir item pernyataan. Adapun hasil uji validitas untuk item pertanyaan pada variabel Keputusan Pembelian (Y) dapat dilihat pada tabel 4.8 Berikut ini:

Tabel 4.8

Hasil Uji Validitas Variabel Keputusan Pembelian

\begin{tabular}{|l|l|l|l|}
\hline No & Item Pernyataan & $\begin{array}{l}\text { Corrected item- } \\
\text { total correlation }\end{array}$ & Keterangan \\
\hline 1 & $\begin{array}{l}\text { Saya menyadari bahwa saya membutuhkan Produk } \\
\text { pasta gigi pepsodent. }\end{array}$ & 0,639 & Valid \\
\hline 2 & $\begin{array}{l}\text { Sebelum memutuskan memilih pepsodent ,Saya } \\
\text { mencari berbagai informasi tentang produk pasta } \\
\text { gigi lainnya. }\end{array}$ & Valid \\
\hline 3 & $\begin{array}{l}\text { Saya melakukan evaluasi perbandingan) atas } \\
\text { informasi yang Saya peroleh tentang produk pasta } \\
\text { gigi pepsoent. }\end{array}$ & Valid \\
\hline 4 & $\begin{array}{l}\text { Keputusan saya memilih produk pasta gigi } \\
\text { pepsodent adalah tepat. }\end{array}$ & Valid \\
\hline 5 & $\begin{array}{l}\text { Saya mengajak atau menyarankan pada orang lain } \\
\text { untuk memilih menggunakan produk pasta gigi } \\
\text { pepsodent. }\end{array}$ & 0,561 & Valid \\
\hline
\end{tabular}

Sumber : Pengolahan data primer, 2018

Hasil uji validitas variabel keputusan pembelian diketahui bahwa semua item pernyataan valid karena nilai koefisien kolerasi ( $\mathrm{r}$ hitung) dari semua item pernyataan lebih besar dari $\mathrm{r}$ kritis $(0,3)$, sehingga semua item pernyataan dimasukkan ke dalam analisis berikutnya. Dengan demikian item pernyataan tentang variabel keputusan pembelian yang akan dianalisis adalah sebanyak 5 item pernyataan.

\subsubsection{Hasil Uji Validitas Variabel Kesadaran Merek}

Variabel kesadaran merek pada penelitian ini di ukur dengan menggunakan 3 butir item pernyataan. Adapun hasil uji validitas untuk item pernyataan pada variabel kesadaran merek $\left(\mathrm{X}_{1}\right)$ dapat dilihat pada tabel 4.9 Berikut ini: 
Tabel 4.9

Hasil Uji Validitas Variabel Kesadaran Merek

\begin{tabular}{|l|l|l|l|}
\hline No & Item Pernyataan & $\begin{array}{l}\text { Corrected } \\
\text { item-total } \\
\text { correlation }\end{array}$ & Keterangan \\
\hline 1 & $\begin{array}{l}\text { Saya dengan cepat mengingat label merek pepsodent } \\
\text { dibanding merek lain. }\end{array}$ & 0,639 & Valid \\
\hline 2 & $\begin{array}{l}\text { Menurut saya produk pasta gigi pepsodent merupakan } \\
\text { produk pasta gigi yang terbaik dibanding produk pasta } \\
\text { gigi lainya }\end{array}$ & 0,716 & Valid \\
\hline 3 & $\begin{array}{l}\text { Karakteristik dari produk pasta gigi pepsodent mudah } \\
\text { saya ingat. }\end{array}$ & 0,674 & Valid \\
\hline
\end{tabular}

Sumber: Hasil Analisis data Primer 2018

Hasil uji validitas variabel kesadaran merek $\left(\mathrm{X}_{1}\right)$ diketahui bahwa semua item pernyataan valid karena nilai koefisien kolerasi ( $\mathrm{r}$ hitung) lebih besar dari $\mathrm{r}$ kritis $(0,3)$, sehingga semua item pernyataan dimasukkan ke dalam analisis berikutnya. Dengan demikian item pernyataan tentang kesadaran merek $\left(\mathrm{X}_{1}\right)$ yang akan dianalisis adalah sebanyak 3 item pernyataan.

\subsubsection{Hasil Uji Validitas Asosiasi Merek}

Variabel asosiasi merek pada penelitian ini di ukur dengan menggunakan 3 butir item pernyataan. Adapun hasil uji validitas untuk item pernyataan pada variabel Asosiasi Merek $\left(\mathrm{X}_{2}\right)$ dapat dilihat pada tabel 4.10 Berikut ini:

Tabel 4.10

Hasil Uji Validitas Variabel Asosiasi Merek

\begin{tabular}{|l|l|l|l|}
\hline No & Item Pernyataan & $\begin{array}{l}\text { Corrected } \\
\text { item-total } \\
\text { correlation }\end{array}$ & Keterangan \\
\hline 1 & $\begin{array}{l}\text { Produk pasta gigi pepsodent sangat berfungsi dan sangat } \\
\text { bermanfaat. }\end{array}$ & 0,711 & Valid \\
\hline 2 & $\begin{array}{l}\text { Ketika saya membicarakan tentang produk pasta gigi, yang } \\
\text { pertama saya ingat adalah merek pepsodent }\end{array}$ & 0,684 & Valid \\
\hline 3 & $\begin{array}{l}\text { "PEPSODENT" merupakan sebuah merek pasta gigi yang } \\
\text { pertama kali saya tahu. }\end{array}$ & 0,840 & Valid \\
\hline
\end{tabular}

Sumber: Hasil Analisis data Primer 2018

Hasil uji validitas variabel asosiasi merek $\left(\mathrm{X}_{2}\right)$ diketahui bahwa semua item pernyataan valid karena nilai koefisien kolerasi ( $\mathrm{r}$ hitung) lebih besar dari $\mathrm{r}$ kritis $(0,3)$, sehingga semua item pernyataan dimasukkan ke dalam analisis berikutnya. Dengan demikian item pernyataan tentang Asosiasi merek $\left(\mathrm{X}_{2}\right)$ yang akan dianalisis adalah sebanyak 3 item pernyataan.

\subsubsection{Hasil Uji Validitas Variabel Persepsi kualitas}

Variabel presepsi kualitas pada penelitian ini di ukur dengan menggunakan 3 butir item pernyataan. Adapun hasil uji validitas untuk item pernyataan pada variabel presepsi kualitas $\left(\mathrm{X}_{3}\right)$ dapat dilihat pada tabel 4.11 Berikut ini: 
Tabel 4.11

Hasil Uji Validitas Variabel Presepsi Kualitas

\begin{tabular}{|l|l|l|l|}
\hline $\begin{array}{l}\text { No. } \\
\text { Item }\end{array}$ & Item Pernyataan & $\begin{array}{l}\text { Corrected item- } \\
\text { total correlation }\end{array}$ & Keterangan \\
\hline 1 & $\begin{array}{l}\text { Produk pasta gigi pepsodent lebih berkualitas } \\
\text { dibandingkan merek lain. }\end{array}$ & 0,613 & Valid \\
\hline 2 & $\begin{array}{l}\text { Sangat masuk akal bila saya memilih produk pasta } \\
\text { gigi pepsodent di banding merek pasta gigi lainnya. }\end{array}$ & 0,709 & Valid \\
\hline 3 & $\begin{array}{l}\text { Pasta gigi Pepsodent sangat nyaman di mulut saat } \\
\text { menggunakannya. }\end{array}$ & 0,806 & Valid \\
\hline
\end{tabular}

Sumber : Pengolahan data primer, 2018

Hasil uji validitas variabel presepsi kualitas $\left(\mathrm{X}_{3}\right)$ diketahui bahwa semua item pernyataan valid karena nilai koefisien kolerasi ( $\mathrm{r}$ hitung) dari item pernyataan lebih besar dari $\mathrm{r}$ kritis $(0,3)$, sehingga item pernyataan dimasukan ke dalam analisis berikutnya. Dengan demikian item pernyataan tentang presepsi kualitas $\left(\mathrm{X}_{3}\right)$ yang akan dianalisis adalah sebanyak 3 item pernyataan.

\subsubsection{Hasil Uji Validitas Variabel Loyalitas Merek}

Dari hasil pengolahan data jawaban responden untuk variabel Loyalitas Konsumen dengan menggunakan Software SPSS Versi 21 dapat diperoleh hasil uji kevaliditasan item - item sebagai berikut:

Tabel 4.12

Hasil Uji Validitas Variabel Loyalitas Merek

\begin{tabular}{|l|l|l|l|}
\hline $\begin{array}{l}\text { No. } \\
\text { Item }\end{array}$ & Item Pernyataan & $\begin{array}{l}\text { Corrected item- } \\
\text { total correlation }\end{array}$ & Keterangan \\
\hline 1 & $\begin{array}{l}\text { Meskipun fitur dari merek pasta gigi pepsodent ini } \\
\text { dengan yang lain sama, saya tetap memilih produk } \\
\text { pasta gigi pepsodent. }\end{array}$ & 0,713 & Valid \\
\hline 2 & $\begin{array}{l}\text { Meski manfaat merek produk pasta gigi pepsodent } \\
\text { dengan merek lain sama bagusnya saya tetap } \\
\text { memilih menggunakan produk pasta gigi } \\
\text { pepsodent. }\end{array}$ & 0,508 & Valid \\
\hline 3 & $\begin{array}{l}\text { Saya fikir, saya setia pada produk pasta gigi merek } \\
\text { pepsodent. } \\
\text { Merek produk pasta gigi pepsodent tetap menjadi } \\
\text { pilihan saya. } \\
\text { Selagi masih ada produk pasta gigi pepsodent saya } \\
\text { tidak akan memilih produk pasta gigi lainnya }\end{array}$ & 0,710 & Valid \\
\hline 5 & 0,560 & Valid \\
\hline
\end{tabular}

Sumber : Pengolahan data primer, 2018

Hasil uji validitas variabel loyalitas merek $\left(\mathrm{X}_{4}\right)$ diketahui bahwa semua item pernyataan valid karena nilai koefisien kolerasi ( $\mathrm{r}$ hitung) dari item pernyataan lebih besar dari $\mathrm{r}$ kritis $(0,3)$, sehingga item pernyataan dimasukan ke dalam analisis berikutnya. Dengan demikian item pernyataan tentang loyalitas merek $\left(\mathrm{X}_{4}\right)$ yang akan dianalisis adalah sebanyak 5 item pernyataan.

\subsection{Uji Reliabilitas}

Uji reliabilitas adalah suatu uji yang menunjukan sejauh mana pengukuran itu dapat memberikan hasil yang relatif tidak beda dilakukan pengulangan pengukuran terhadap subyek yang sama. Uji ini hanya dapat dilakukan pada pernyataan/pernyataan yang valid saja. Pengujian reliabilitas dilakukan dengan menggunakan rumus alpha atau Cronbach's Alpha, instrumen yang mempunyai reliabilitas. Instrumen yang dipakai dalam variabel yang dikatakan handal apabila memiliki Cronbach's Alpha lebih dari 0,70 Singgih Santoso (2001). Hasil 
analisis reliabilitas diketahui bahwa nilai Koefisien Cronbach's Alpha dari masing-masing variabel dapat dilihat pada tabel 4.13 berikut ini:

Tabel 4.13

Hasil Uji Reliabilitas Variabel Penelitian

\begin{tabular}{|l|l|l|l|l|}
\hline No & Variabel & Notasi & Cronbach's Alpha & Keterangan \\
\hline 1 & Keputusan Pembelian & $(\mathrm{Y})$ & 0,703 & Reliabel \\
\hline 2 & Kesadaran Merek & $\left(\mathrm{X}_{1}\right)$ & 0,749 & Reliabel \\
\hline 3 & Asosiasi Merek & $\left(\mathrm{X}_{2}\right)$ & 0,772 & Reliabel \\
\hline 4 & Presepsi Kualitas & $\left(\mathrm{X}_{3}\right)$ & 0,876 & Reliabel \\
\hline 5 & Loyalitas Merek & $\left(\mathrm{X}_{4}\right)$ & 0,723 & Reliabel \\
\hline
\end{tabular}

Sumber: Hasil Analisis data Primer 2018

Berdasarkan hasil uji reliabilitas sebagaimana yang terlihat pada tabel 4.13 terlihat bahwa semua variabel memiliki nilai Cronbach's Alpha lebih besar dari 0,7. Variabel kesadaran merek $\left(\mathrm{X}_{1}\right)$ memiliki Cronbach's Alpha sebesar 0,749, Variabel Asosiasi Merek $\left(\mathrm{X}_{2}\right)$ memiliki Cronbach's Alpha sebesar 0,772, variabel presepsi Kualitas $\left(\mathrm{X}_{3}\right)$ memiliki nilai Cronbach's Alpha sebesar 0,876, variabel Loyalitas Merek (x4) sebesar 0,723 dan variabel keputusan pembelian (y) memiliki croambact alpha sebesar 0,703 . Hal ini menandakan bahwa semua variabel penelitian memiliki kuisioner yang handal dan reliabel. Dengan demikian dapat dikatakan bahwa kuisioner yang digunakan untuk mengumpulkan data penelitian sangat handal.

\subsection{Uji Asumsi Klasik \\ 4.4.1 Uji Linieritas}

Uji ini digunakan untuk melihat apakah spesifikasi model yang digunakan sudah benar atau tidak. Apabila titik-titik distribusi mengikuti garis linier, maka model regresi dapat dinyatakan linier, dalam penelitian ini, untuk uji linieritas dipergunukan grafik P-P. Plot. Berikut ini adalah hasil pengujian linieritas:

\section{Grafik 4.1}

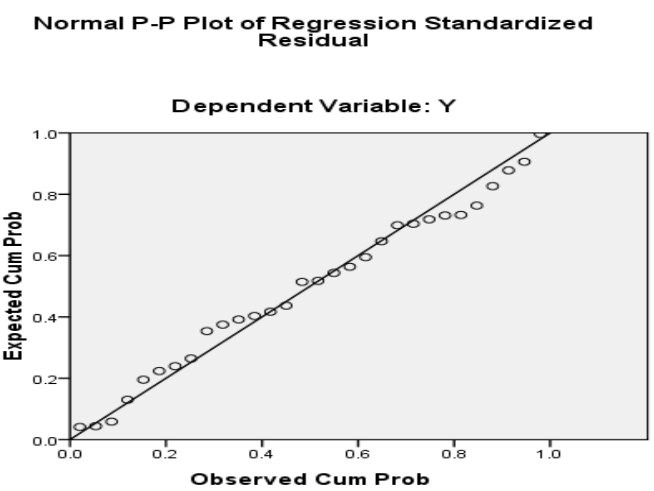

Berdasarkan grafik diatas, terlihat bahawa titik-titik bergerak menuju searah dengan garis linier, sehingga dapat disimpulkan bahawa model regresi penelitian ini adalah linier 


\subsubsection{Uji Normalitas}

Menurut Santoso (2007), uji normalitas berpedoman pada uji Kolmogorov Smirnov yang pengujian nya secara multivariate. Residual dinyatakan terdistribusi normal yaitu:

1. Jika nilai signifikansi $<0,05$ (taraf kepercayaan $95 \%$ ) distribusi adalah tidak normal.

2. Jika nilai signifikansi $>0,05$ (taraf kepercayaan $95 \%$ ) distribusi adalah normal

\begin{tabular}{|c|c|c|}
\hline \multicolumn{3}{|c|}{ One-Sample Kolmogorov-Smirnov Test } \\
\hline & & $\begin{array}{l}\text { Unstandardized } \\
\text { Residual }\end{array}$ \\
\hline $\begin{array}{l}\text { N } \\
\text { Normal Parameters } \\
\text { Most Extreme Differences } \\
\text { Kolmogorov-Smirnov Z } \\
\text { Asymp. Sig. (2-tailed) }\end{array}$ & $\begin{array}{l}\text { Mean } \\
\text { Std. Deviation } \\
\text { Absolute } \\
\text { Positive } \\
\text { Negative }\end{array}$ & $\begin{array}{l}94 \\
, 0000000 \\
, 33203960 \\
, 121 \\
, 058 \\
-, 121 \\
1,175 \\
, 126\end{array}$ \\
\hline
\end{tabular}

Gambar 4.1 Uji Normalitas

Dari tabel diatas terlihat bahwa nilai kolmogrof simirnov 1,175 dengan signfikan pada 0,126 hal ini berarti data residual terdistribusi normal. Jadi secara simultan menunjukan kondisi normal sehingga dari segi normalitas data memenuhi syarat untuk dilakukan analisis data dengan regresi.

\subsubsection{Uji Multikolinieritas}

Untuk mengetahui ada tidaknya multikolinearitas dalam model regregi dapat dilihat melalui VIF (Varians Inflation Factor). Bila angka tolerance $>1$ atau nilai VIF $>10$, maka terdapat gejala multikolinearitas. Hasil uji multikolinearitas dapat dilihat pada tabel 4.19 berikut ini :

Tabel 4.19

\section{Uji Multikolinearitas}

\begin{tabular}{|l|l|l|}
\hline \multirow{2}{*}{ Model } & Collinearity Statistics \\
\cline { 2 - 3 } & Tolerance & VIF \\
\hline KMerek &, 595 & 1,681 \\
AMerek &, 610 & 1,640 \\
PKualitas &, 634 & 1,578 \\
Lmerek &, 634 & 1,578 \\
\hline
\end{tabular}
Dependent variabel k.Pembelian

Berdasarkan hasil analisis regresi berganda pada tabel 4.19 di atas, terlihat bahwa semua variabel bebas dalam penelitian ini yaitu Kesadaran merek, asosiasi merek, presepsi kualitas dan loyalitas merek nilai tolerancenya tidak ada yang kecil dari 0,1 dan nilai VIF tidak ada yang besar dari 10. Nilai tolerance Kesadaran Merek 0.598, Asosiasi Merek 0.610 Presepsi Kualitas 0,634 dan Loyalitas Merek 0,634. Hal yang sama juga terjadi pada nilai VIF, dimana nilai VIF kesadaran merek 1,681, Asosiasi Merek 1.640, Presepsi Kualitas 1,578 dan loyalitas merek 1,578. Dengan demikian di antara variabel independen dinyatakan bebas dari multikolinearitas.

\subsubsection{Uji Heteroskedastisitas}

Untuk menguji ada tidaknya heterokedastisitas dapat dilihat dari grafik Plott (Scatterplot). Jika ada pola tertentu, seperti titik-titik yang ada membentuk pola tertentu yang teratur (bergelombang, melebar kemudian menyamping), maka mengindikasikan telah terjadi 
heterokedastisitas. Jika tidak ada pola yang jelas, serta titik-titik menyebar di atas dan di bawah angka 0 (nol) pada sumbu Y, maka tidak terjadi heteroskedastisitas.

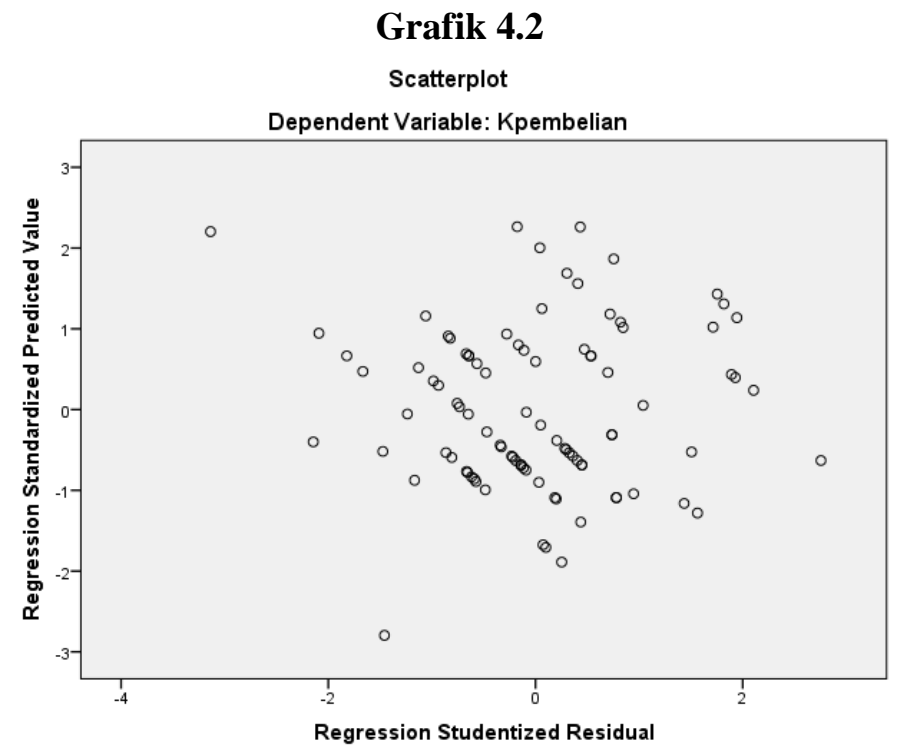

Sumber : Pengolahan Data Primer 2018

Dari grafik Scatterplot di atas, tidak ditemukan terbentuknya pola-pola tertentu dari penyebaran titik-titik pada grafik. Oleh karena itu dapat disimpulkan bahwa model regresi dalam penelitian ini adalah homoskedastisitas atau tidak terjadi heteroskedastisitas

\subsection{Hasil Analisis Regresi Linear Berganda}

Analisis regresi linear berganda (multiple regression analysis) digunakan untuk mengetahui seberapa besar pengaruh beberapa variabel bebas terhadap variabel terikat (Kuncoro, 2003). Analisis regresi berganda dalam penelitian ini bertujuan untuk mengetahui seberapa besar pengaruh variabel kesadaran merek, asosiasi merek, presepsi kualitas dan loyalitas merek terhadap keputusa pembelian . Hasil analisis regresi linear berganda dapat dilihat pada tabel 4.20 berikut ini :

Tabel 4.20

Ringkasan Hasil Analisa Regresi Berganda

\begin{tabular}{|l|l|l|l|l|}
\hline Variabel & $\begin{array}{l}\text { Koefisien } \\
\text { Regresi }\end{array}$ & $\mathbf{t}_{\text {hitung }}$ & Sig & Keterangan \\
\hline Konstanta & 0.899 & 5.233 & 0.000 & - \\
\hline Kesadaran Merek X1 & 0.045 & 0.542 & 0.589 & Tidak Signifikan \\
\hline Asosiasi Merek X2 & 0.111 & 1.628 & 0.107 & Tidak Signifikan \\
\hline Presepsi Kualitas X3 & 0.292 & 4.533 & 0.000 & Signifikan \\
\hline Loyalitas Merek x4 & 0,132 & 1.408 & 0,163 & Tidak Signifikan \\
\hline Koefisien Korelasi (R) & $: 0.632$ & & \\
Koefisien Determinan $\quad\left(\mathrm{R}^{2}\right)$ & $: 0.400$ & & & \\
Nilai F & $: 14,835$ & & & \\
Signifikan F & $: 0.000$ & & & \\
& & &
\end{tabular}

Sumber : Pengolahan Data Primer 2018

Tabel 4.20 memperlihatkan nilai konstanta $(\alpha)$ adalah 1,889 sedangkan nilai koefisien kesadran merek ,045, Asosiasi Merek .111 presepsi kualitas .292 dan loyalitas merek 132. 


\subsection{Pengujian Hipotesis}

Adapun hipotesis yang telah dikembangkan dalam penelitian ini dapat dilihat sebagai berikut:

Hipotesis (H1) : Kesadaran merek berpengaruh positif tetapi tidak signifikan terhadap keputusan pembelian.

Hipotesis (H2): Asosiasi merek berpengaruh positif tetapi tidak signifikan terhadap Keputusan pembelian.

Hipotesis (H3) : Persepsi kualitas berpengaruh positif dan signifikan terhadap Keputusan pembelian.

Hipotesis (H4) : Loyalitas merek, berpengaruh positif tetapi tidak signifikan terhadap Keputusan pembelian.

Hipotesis (H4) : Kesadaran merek, Asosiasi merek, persepsi kualitas dan Loyalitas merek berpengaruh positif dan signifikan secara bersama-sama (simultan) terhadap Keputusan pembelian.

Berdasarkan pengujian hipotesis yang telah dilakukan, berikut ini dapat dikemukakan persamaan regresi linear berganda sebagai berikut:

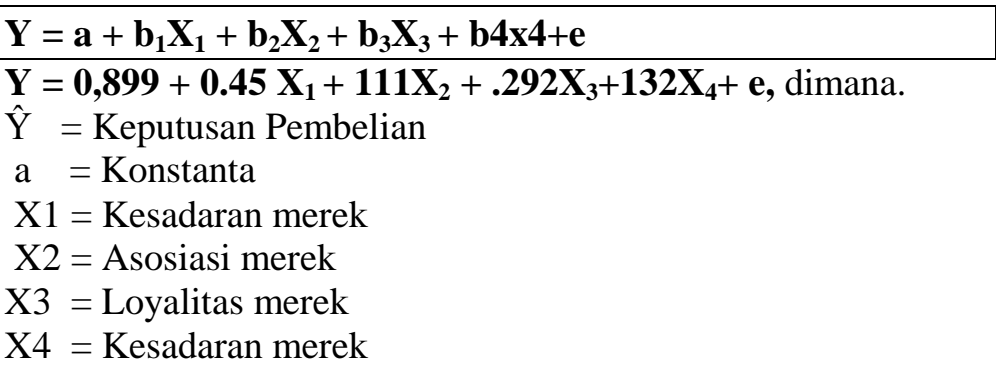

\section{Kesimpulan}

Berdasarkan hasil penelitian yang ditemukan oleh peneliti yang berjudul Pengaruh Elemen Ekuitas Merek terhadap keputusan pembelian produk pasta gigi pepsodent dikecamatan kinali maka diperoleh kesimpulan terkait pencapaian analisa serta hipotesis yang diajukan yakni sebagai berikut:

1. Keputusan Pembelian yang dilakukan konsumen produk pasta gigi pepsodent tergolong kurang baik dengan skor rata-rata sebesar 4,04 dengan tingkat pecapaian sebesar 64,36\%.

2. Kesadaran Merek terhadap produk pasta gigi pepsodent masyarakat kecamatan kinali tergolong Baik dengan skor rata-rata sebesar 4,16 dengan tingkat pencapaian sebesar $83,26 \%$

3. Asosiasi merek produk pasta gigi pepsodent dikecamatan kinali tergolong cukup baik dengan skor rata-rata sebesar 3,83 dengan tingkat pencapaian sebesar 76,33\%.

4. Presepsi kualitas produk pasta gigi pepsodent dikecamatan kinali tergolong cukup baik dengan skor rata-rata 3,56 dengan tingkat pencapaian 72,00\%.

5. Loyalitas merek terhadap produk pasta gigi pepsodent dikecamatan kinali tergolong cukup baik dengan skor rata-rata sebesar 3,66 dengan tingkat pencapaian 73,24\% .

6. Berdasarkan hasil perhitungan pada hipotesis ketiga didapat hasil $\mathrm{F}$ hitung sebesar 14.835 dengan nilai signifikan sebesar 0,000. Dengan demikian hipotesis 3 diterima, artinya kesadaran merek, asosiasi merek, presepsi kuaitas dan loyallitas merek secara bersamaan berpengaruh signifikan terhadap keputusan pembelian produk pasta gigi pepsodent pada masyarakat kecamatan kinali.Koefisien determinasi menunjukkan bahwa kemampuan variabel kesadran merek, asosiasi merek,presepsi kualitas dan kesadaran merek terhadap keputusan pembeian produk pasta gigi pepsodent dikaecamatan kinali adalah sebesar 0,400 atau $40 \%$. Hal ini menunjukkan bahwa kontribusi semua variabel independen yang diteliti dalam penelitian ini adalah sebesar $40 \%$. Selebihnya yaitu $60 \%$ lagi dipengaruhi variabel lain yang tidak diteliti pada penelitian ini. 


\section{DAFTAR PUSTAKA}

[1] Arikunto, S (2006). Prosedur Penelitian, Suatu Pendekatan Praktek. PT. Rineka Cipta.Jakarta

[2] Durianto, Darmadi, Sugiarto dan Toni Sitinjak,( 2001). Strategi Menaklukan Pasar : Melalui Riset Ekuitas dan Perlaku Merek. PT Gramedia Pustaka Utama, Jakarta.

[3] Durianto, Darmadi, Sugiarto, Budiman, L.J. (2004). Strategi Menaklukan Pasar Melalui Riset Ekuitas Dan Prilaku Merek, Jakarta :Pt Gramedia Pustaka Utama.

[4] Durianto, Sugiarto \& Budiman. (2004). Brand Equity Ten: Strategi Memimpin Pasar,Jakarta: PT. Gramedia Pustaka Utama.

[5] Ghozali, Imam. (2007). Aplikasi Analisis Multivariate dengan Program SPSS. Badan Penerbit Universitas Diponegoro, Semarang.

[6] Kotler, Keller, (2006), Marketing Management, $12^{\text {th }}$ Edition, New joney: Presentive Hall International,Inc.

[7] Kotler, Philip, 2002. Manajemen Pemasaran : Jilid 2.Jakarta: Prenhallindo.

[8] Kotler, Philip.2005. Management Pemasaran. Edisi II. Jakarta: PT. Indeks.

[9] Kotler dan Amstrong (2008) Prinsip-prinsip pemasaran . edisi 12, jilid 1 Erlangga,Jakarta

[10] Keller dan Kotler,(2009).Manajement pemasaran , diterjemahkan oleh sabran bo

[11] Kotler, Philip dan Keller, Kevin Lane.2007. Manajemen Pemasaran. Edisi 12, jakarta:PT Indeks.

[12] Kotler, Philip \& Kevin Lare Keller. (2008). Manajemen Pemasaran. Edisi Dua Belas Jilid 1. Alih Bahasa Benyamin Molan. Indeks. Jakarta

[13] Kotler, Philip.(2004). Prinsip-Prinsip Pemasaran. Edisi 12, Jilid 1. Erlangga. Jakarta

[14] Kotler. Philip. (2009). Manajemen Pemasaran. Erlangga. Jakarta.

[15] Kuncoro. Mudrajad. (2003). Metode Riset Untuk Bisnis Dan Ekonomi. Erlangga. Jakarta (2004). Atonomi dan pembagunan daerah, Erlangga. Jakarta.

[17] Philip Kotler \& Kevin Lane Keller (2006). Manajemen Pemasaran. Ghalia. Indonesia.

[18] Philip Kotler \& Kevin Lane Keller (2006). Manajemen Pemasaran. Ghalia. Indonesia.

[19] Sugiarto, dkk (2001), Teknik Sampling,Jakarta: Gramedia Pustaka Utama.

[20] Simamora, Bilson. (2007). Panduan Riset Dan Prilaku Konsumen. Jakarta: PT. Gramedia Pustaka.

[21] Sugiyono. (2005). Metode Penelitian Bisnis Bandung. CV. Alphabeta.

[22] Sugiyono (2009). Metode Penelitian Kuantitatif dan Kualitatif. $\quad$ CV.Alfabeta: Bandung Universitas Deponegoro : Semarang.

[23] Sugiyono, 2010, Metode Penelitian Kualitatif Dan Kuantitatif dan R\&D, Alfabeta, Bandung.

[24] Surachman. (2008) Dasar-dasar Manajemen Merek. Malang Banyumedia Publishing.

[25] Simamora, Bilson, 2002, Panduan Riset Perilaku Konsumen, PT Gramedia Pustaka Utama Jakarta. 